\title{
The Investigation of Exposure to Silicate Powders in Patients Diagnosed Silicosis
}

Journal of Medical Clinical Case Reports

Research Article

\author{
Abdullah Talha TURKMEN ${ }^{1}$, Ozan Emre EYUPOGLU ${ }^{2 *}$ and Gulden Zehra OMURTAG ${ }^{3}$ \\ ${ }^{1}$ Istanbul Technical University, Rectorate, Corporate Affairs \\ and Alumni Communication Office, Istanbul, Turkey. \\ ${ }^{2}$ Istanbul Medipol University, School of Pharmacy, \\ Department of Biochemistry, Istanbul, Turkey. \\ ${ }^{3}$ Istanbul Medipol University, School of Pharmacy, \\ Department of Pharmaceutical Toxicology, Istanbul, Turkey. \\ *Correspondence author \\ Dr. Ozan Emre EYUPOGLU \\ Istanbul Medipol University \\ School of Pharmacy \\ Basic Science of Pharmacy \\ Biochemistry Department \\ Kavacik South Campus \\ Beykoz / Istanbul \\ Turkey \\ Orcid ID: 0000-0002-4449-0537
}

Submitted : 24 Dec 2020 ; Published : 23 Jan 2021

\begin{abstract}
Silicosis, in the textile sector in 2005, was first reported and defined as an occupational disease in Turkey. The process of spraying the sea sand through the fabric with the help of a compressor is called "sandblasting" to bleach, abrading, and aging the jeans. Exposure to sand dust in the working environment, the absence of occupational health and safety measures at the workplace, causes silicosis disease to be observed in the employees who perform denim sandblasting. Within the scope of this thesis, a descriptive epidemiological study was carried out aiming to reach with 45 persons who worked in Istanbul for a certain period in sandblasting and were subsequently diagnosed with silicosis. The main data of this thesis are the socio-economic conditions, demographic characteristics, working conditions as well as information about the working conditions of the patients, and the duration of the disease are also included. All the individuals in the thesis study are male and average $39.40 \pm 8.65$ years old. All employees $(100 \%, n=45)$ have not been subjected to an employment examination. All the employees work 6 days a week, 42.9\% work in two shifts, and $57.1 \%$ work in three shifts. The distribution of the daily working time of the employees is $8-9$ hours of $84.4 \%, 10-11$ hours of $13.3 \%$, and over 12 hours of $2.2 \%$. The proportion of employees without insurance is $93.3 \%(n=42)$ and the rate of insured employees is $6.7 \%(n=3)$ for a while. During the medical examination, $71.1 \%(n=32)$ of the employees started after work, $17.8 \%(n=8)$ after quitting the job and $11.1 \%(n=5)$ before the military service. It has received. Also, $8.9 \%(n=4)$ of the patients were diagnosed with tuberculosis. The rate of those who document that the disease is an occupational disease is $2.2 \%$. $(N=1)$. In the thesis, especially silicosis and tuberculosis has been shared literature about lung cancer diseases, powdery substance in Turkey and is given to current regulations for crystalline silica. Besides, the results obtained from the survey conducted within the scope of the thesis were shared. The importance of occupational health and safety rules has been emphasized to prevent occupational diseases among those working in workplaces applying the "sandblasting" process.
\end{abstract}

Keywords: Silicosis, Denim sandblasting, Occupational disease, Siliceous powders, Exposure

\section{Introduction}

Silicon dioxide, also known as silica, is an oxide of silicon with the chemical formula ( $\mathrm{SiO} 2)$, found in earth crust $[1,2]$. Its wide range of use and common presence in nature make silica exposure inevitable $[3,4]$. Silica in crystalline forms is called free silica [5]. Non-crystalline form of silica, on the other hand, is known as amorphous silica (quartz). Compared to free silica, aerosols of synthetic amorphous silica do not induce fibrosis in the lungs after inhalation $[2,6,7]$.

The World Health Organization (WHO) defines health as a "state of complete physical, mental, and social well-being and not merely the absence of disease or infirmity" [8]. One of the fundamental human rights is the right to a standard of living adequate for the health and well-being of himself and of his family [9].

Due to the rapid growth of industrialization, the globalization of capital, the idea of gaining more profit with the low wages for labor, and high unemployment rates, subhuman working conditions spread all over the world. Governments' insufficient regulations on occupational health and safety lead to situations that threaten the health and safety of workers in many sectors [10]. The concept of occupational disease, therefore, is also among the risk factors that arise from inappropriate working 
environments and can sometimes lead to fatal consequences. Taking precautions against risk factors may prevent many occupational diseases [11].

Although the social awareness of occupational diseases increases, the desired level of prevention could not be reached. On the other hand, it is observed that the number of cases diagnosed with occupational diseases and resulting in death has increased with each passing year [12].

One of the occupational diseases that cause lung damage is silicosis, which is caused by the inhalation of crystalline silica dust. It is a disease that may lead to incurable consequences when preventive measures are not taken. In Turkey, the silicosis cases were identified in the 2000s. Silicate dusts in the inhaled air arising from the sandblasting process, which involves the removal of the dark indigo pigment by blasting small particles of sand at high pressures against the fabric to soften and lighten the garment, cause irreversible damage to the lungs. Deaths at young ages and respiratory failure have been observed in cases in Turkey.

Since it leads to silicosis disease in the textile industry, the sandblasting is prohibited by government officials with the joint initiatives of various non-governmental organizations in Turkey. There is not enough epidemiological data in the literature.

Although some of the workers diagnosed with silicosis in Turkey have availed of rights such as disability payment and compensation, still many of them have not been able to avail of these rights. In order for workers to avail of these rights, state authorities need to make studies.

Dealing with epidemiological aspects of individuals diagnosed with silicosis, this study aims to question the level of awareness of people about silicate dust in the environments exposed to and to raise awareness of the health effects of silicosis in terms of occupational health and safety among employees.

\section{Method}

The sample of this study includes a total of 45 cases, who reside in Taşlıçay village of Karlıova district in Bingol province and arrived in Istanbul to work, who were aged between 27 and 61 years (mean age $39.40 \pm 8.65$ years). The data were obtained using questionnaire method through face-to-face interviews on 27-28 July 2019.

The questionnaire applied within the scope of the thesis was prepared to determine the following information from individuals diagnosed with silicosis:

- Level of educational

- Marital status

- Previous workplaces and employment period

- Smoking status

- Employment method

- Average daily working hours
- Whether they asked about any health problems related to the job?

- Whether any precaution was taken against occupational safety

- Insurance status

- The first reason to visit the doctor

- Time to diagnosis

- Procedures for diagnosis

- Whether tuberculosis treatment was applied before silicosis diagnosis

- Whether they documented their diseases as an occupational disease

- Whether they availed of their legal rights

NCSS (Number Cruncher Statistical System) 2007 Statistical Software (NCSS LLC, Kaysville, Utah, USA) program was used for the statistical analysis of the data obtained as a result of the survey applied within the scope of the study. While evaluating the study data, in addition to descriptive statistical methods (mean, standard deviation, median, frequency and ratio), the Shapiro-Wilks test and Boxplot graphics were used to evaluate the suitability of the data to normal distribution. The Student t-test was used for pairwise evaluation of normally distributed variables, while one-way ANOVA test for making multiple (three and more) comparisons, and the Bonferroni test for determining which means are significantly different. The Mann-Whitney U test was used to compare differences between two independent groups on a dependent but not normally distributed variable, while the Kruskal-Wallis test was used for comparisons of three and more than three groups, and Dunn's test was used for determining the group causing the difference. On the other hand, Pearson's Chi-Squared test, Yates's Continuity Correction, Fisher's Exact test, and the Fisher-Freeman-Halton Test was used to compare qualitative data, results were evaluated at $95 \%$ confidence interval and significance level of $\mathrm{p}<0.05$.

\section{Results}

The sample of this study includes a total of 45 cases, who reside in Taşlıçay village of Karlıva district in Bingol province and arrived in Istanbul to work, who were aged between 27 and 61 years (mean age $39.40 \pm 8.65$ years) (Table 1). The data were collected through a face-to-face interview method on 27-28 July 2019.

\begin{tabular}{|l|l|l|}
\hline \multirow{3}{*}{ Age (years) } & Min-Max (Median) & $27-61(38)$ \\
\cline { 2 - 3 } & Mean \pm Sd & $39.40 \pm 8.65$ \\
\hline \multirow{5}{*}{ Level of education } & Literate & $3(6.7)$ \\
\cline { 2 - 3 } & Primary & $29(64.4)$ \\
\cline { 2 - 3 } & Secondary & $2(4.4)$ \\
\cline { 2 - 3 } & High School & $8(17.8)$ \\
\cline { 2 - 3 } & University & $3(6.7)$ \\
\hline Marital status & Married & $41(91.1)$ \\
\cline { 2 - 3 } & Single & $4(8.9)$ \\
\hline
\end{tabular}




\begin{tabular}{|c|c|c|}
\hline \multirow[t]{4}{*}{ Number of children } & None & $4(8.9)$ \\
\hline & $1-2$ & $9(20.0)$ \\
\hline & $3-4$ & $25(55.6)$ \\
\hline & 5 and more & $7(15.6)$ \\
\hline \multirow{3}{*}{$\begin{array}{l}\text { Total number of } \\
\text { people living } \\
\text { in household }\end{array}$} & $3-4$ & $11(24.4)$ \\
\hline & $5-6$ & $23(51.1)$ \\
\hline & $\geq 7$ & $11(24.4)$ \\
\hline \multirow[t]{2}{*}{ Smoking status } & Current smoker & $37(82.2)$ \\
\hline & Non-smoker & $8(17.8)$ \\
\hline \multirow[t]{2}{*}{ Cigarettes per day } & Min-Max (Median) & $15-40(20)$ \\
\hline & Mean $\pm S d$ & $20.68 \pm 4.88$ \\
\hline \multirow[t]{2}{*}{ Smoking duration } & Min-Max (Median) & $8-40(20)$ \\
\hline & $M e a n \pm S d$ & $22.00 \pm 9.52$ \\
\hline \multirow{3}{*}{$\begin{array}{l}\text { The reason to arrive } \\
\text { in } \\
\text { Istanbul }\end{array}$} & Economic reasons & $41(91.1)$ \\
\hline & Forced migration & $3(6.7)$ \\
\hline & Education & $1(2.2)$ \\
\hline
\end{tabular}

Table 1: Distributions of Demographic Characteristics

In terms of the level of education; of the participants, $6.7 \%$ $(n=3)$ were literate, $29 \%(n=29)$ primary school, $4.4 \%(n=2)$ secondary school, $8 \%(\mathrm{n}=17.8)$ high school and $6.7 \%(\mathrm{n}=3)$ were university graduates (Table 1).

\begin{tabular}{|c|c|c|}
\hline & & $\mathrm{n}(\%)$ \\
\hline \multirow[t]{18}{*}{ Current Profession } & Digger operator & $8(17.8)$ \\
\hline & Construction laborer & $6(13.3)$ \\
\hline & Husbandry & $4(8.9)$ \\
\hline & Lorry driver & $4(8.9)$ \\
\hline & Road maintenance laborer & $3(6.7)$ \\
\hline & Master carpenter & $3(6.7)$ \\
\hline & Unemployed & $3(6.7)$ \\
\hline & Accounting & $2(4.4)$ \\
\hline & Secretary & $2(4.4)$ \\
\hline & Self-employed & $2(4.4)$ \\
\hline & Sales & $1(2.2)$ \\
\hline & Foremen & $1(2.2)$ \\
\hline & Car painter & $1(2.2)$ \\
\hline & Chief of progress payment & $1(2.2)$ \\
\hline & Warehouseman & $1(2.2)$ \\
\hline & Calenderer & $1(2.2)$ \\
\hline & Tailor & $1(2.2)$ \\
\hline & Manager & $1(2.2)$ \\
\hline \multirow{3}{*}{$\begin{array}{l}\mathrm{E} \mathrm{mpl} \text { o y } \mathrm{m} \text { e } \mathrm{nt} \\
\text { period (months) }\end{array}$} & 3-6 months & $3(6.7)$ \\
\hline & 6-12 months & $30(66.7)$ \\
\hline & 12 months and above & $12(26.7)$ \\
\hline
\end{tabular}

Table 2: Distribution of Occupational Status

In terms of current professions of the participants, the distribution was as follows: $17.8 \%(n=8)$ digger operator,
$13.3 \%(n=6)$ construction laborer, $8.9 \%(n=4)$ husbandry, $8.9 \%(\mathrm{n}=4)$ lorry driver, $6.7 \%(\mathrm{n}=3)$ road maintenance laborer, $6.7 \%(n=3)$ master carpenter and other professions (Table 2$)$.

\begin{tabular}{|c|c|c|}
\hline $\begin{array}{l}\text { P r e v i o u s } \\
\text { occupations }\end{array}$ & & n $(\%)$ \\
\hline $\begin{array}{l}\text { First occupation } \\
\text { (Sandblasting of } \\
\text { denim) }\end{array}$ & & $45(100.0)$ \\
\hline \multirow[t]{2}{*}{ Period (years) } & $\begin{array}{l}M i n-M a x \\
\text { (Median) }\end{array}$ & $0.08-6.00(0.75)$ \\
\hline & Mean $\pm S d$ & $0.90 \pm 0.85$ \\
\hline \multirow[t]{12}{*}{ Second occupation } & $\begin{array}{l}\text { Construction } \\
\text { laborer }\end{array}$ & $25(55.6)$ \\
\hline & Denim washing & $6(13.3)$ \\
\hline & Calenderer & $3(6.7)$ \\
\hline & Sandpit laborer & $2(4.4)$ \\
\hline & Salesman & $2(4.4)$ \\
\hline & Tea vendor & $1(2.2)$ \\
\hline & Furniture & $1(2.2)$ \\
\hline & Car body painter & $1(2.2)$ \\
\hline & Husbandry & $1(2.2)$ \\
\hline & Denim cut & $1(2.2)$ \\
\hline & Textile laborer & $1(2.2)$ \\
\hline & Tailor & $1(2.2)$ \\
\hline \multirow[t]{2}{*}{ Period (years) } & $\begin{array}{l}M i n-M a x \\
\text { (Median) }\end{array}$ & $1-30(5)$ \\
\hline & Mean $\pm S d$ & $7.02 \pm 6.35$ \\
\hline \multirow[t]{16}{*}{ Third occupation } & Unemployed & $8(17.8)$ \\
\hline & Digger operator & $8(17.8)$ \\
\hline & Husbandry & $6(13.3)$ \\
\hline & Lorry driver & $4(8.9)$ \\
\hline & Master carpenter & $3(6.7)$ \\
\hline & Accounting & $2(4.4)$ \\
\hline & Secretary & $2(4.4)$ \\
\hline & Self-employed & $2(4.4)$ \\
\hline & Calenderer & $2(4.4)$ \\
\hline & $\begin{array}{l}\text { Road maintenance } \\
\text { laborer }\end{array}$ & $2(4.4)$ \\
\hline & Denim sales & $1(2.2)$ \\
\hline & $\begin{array}{l}\text { Construction } \\
\text { laborer }\end{array}$ & $1(2.2)$ \\
\hline & Manager & $1(2.2)$ \\
\hline & Foremen & $1(2.2)$ \\
\hline & $\begin{array}{l}\text { Chief of progress } \\
\text { payment }\end{array}$ & $1(2.2)$ \\
\hline & Warehouseman & $1(2.2)$ \\
\hline \multirow[t]{2}{*}{ Period (years) } & $\begin{array}{l}M i n-M a x \\
\text { (Median) }\end{array}$ & $1-25(9)$ \\
\hline & Mean $\pm S d$ & $9.19 \pm 5.85$ \\
\hline
\end{tabular}

Table 3: Distribution of Previous Occupations 
It was seen that the first profession of $100 \%(n=45)$ of the participants were sandblasting of denim. The participants' working period in their first occupation ranged from 0.08 to 6 , and the mean was found to be $0.90 \pm 0.85$ years. It was found that $77.8 \%(n=35)$ of the participants worked less than one year, and $22.2 \%(n=10)$ worked for one year and above. In terms of second occupations; $55.6 \%(n=25)$ of them worked as construction laborers, while $13.3 \%(n=6)$ in denim washing, $6.7 \%(\mathrm{n}=3)$ as calenderers, $4.4 \%(\mathrm{n}=2)$ as sandpit laborers, and $4.4 \%(n=2)$ as salesman. The period to work in the second occupation ranged from 1 to 30 years, and the mean was $7.02 \pm 6.35$ years (Table 3 ).

\begin{tabular}{|c|c|c|}
\hline \multirow[t]{2}{*}{ Employment Method } & His own means & $5(11.1)$ \\
\hline & $\begin{array}{l}\text { By means of friend/ } \\
\text { relative }\end{array}$ & $40(88.9)$ \\
\hline \multirow{2}{*}{$\begin{array}{l}\text { Pre-Employment Health } \\
\text { Examination }\end{array}$} & No & $45(100.0)$ \\
\hline & Yes & $0(0.0)$ \\
\hline \multirow[t]{3}{*}{ Daily working hours } & 8-9 hours & $38(84.4)$ \\
\hline & 10-11 hours & $6(13.3)$ \\
\hline & $\geq 12$ hours & $1(2.2)$ \\
\hline \multirow{3}{*}{$\begin{array}{l}\text { Number of working } \\
\text { days per week }\end{array}$} & 6 Days & $45(100.0)$ \\
\hline & No & $24(53.3)$ \\
\hline & Yes & $21(46.7)$ \\
\hline \multirow[t]{2}{*}{ Number of shifts } & 2 Shifts & $9(42.9)$ \\
\hline & 3 Shifts & $12(57.1)$ \\
\hline \multirow[t]{2}{*}{ Total number of staff } & Min-Max (Median) & $6-30(10)$ \\
\hline & $M e a n \pm S d$ & $11.71 \pm 4.57$ \\
\hline \multirow{2}{*}{$\begin{array}{l}\text { Have they been informed } \\
\text { about health risks in the } \\
\text { workplace? }\end{array}$} & Yes & $0(0.0)$ \\
\hline & No & $45(100.0)$ \\
\hline \multirow{7}{*}{$\begin{array}{l}\text { Did he or she asked } \\
\text { about any health } \\
\text { problems related to the } \\
\text { job? }\end{array}$} & Yes & $1(2.2)$ \\
\hline & No & $44(97.8)$ \\
\hline & Ignorance & $2(4.4)$ \\
\hline & Not thought & $39(86.7)$ \\
\hline & Found unnecessary & $2(4.4)$ \\
\hline & $\begin{array}{l}\text { Since he's informed } \\
\text { that 'no health } \\
\text { problem risk' }\end{array}$ & $1(2.2)$ \\
\hline & $\begin{array}{l}\text { Supervisor didn't } \\
\text { take care of } \\
\text { themselves }\end{array}$ & $1(2.2)$ \\
\hline \multirow{3}{*}{$\begin{array}{l}\text { *Taking a precaution for } \\
\text { occupational safety }\end{array}$} & Mask & $39(86.7)$ \\
\hline & Goggles & $26(57.8)$ \\
\hline & Ventilation & $17(37.8)$ \\
\hline \multirow[t]{3}{*}{ Insurance } & Yes & $0(0.0)$ \\
\hline & None & $42(93.3)$ \\
\hline & Term insurance & $3(6.7)$ \\
\hline
\end{tabular}

\begin{tabular}{|l|l|l|}
\hline & 1 month & $1(33.3)$ \\
\hline & 2 months & $1(33.3)$ \\
\hline & 3 months & $1(33.3)$ \\
\hline
\end{tabular}

*Multiple options were marked.

Table 4: Distributions of Features of Current Profession

$11.1 \%(n=5)$ of the participants stated that they found the job they work by their own means, while $88.9 \%(n=40)$ mentioned that they found their job by means of their friends/relatives.

$100 \%(n=45)$ of the patients stated that no pre-employment health examinations were made.

In terms of the daily working hours; $84.4 \%(n=38)$ of the participants stated that they work for $8-9$ hours, $13.3 \%(n=6)$ 10-11 hours, and 2.2\% $(\mathrm{n}=1) 12$ hours and over.

$100 \%$ of the participants stated that they work for 6 days in a week.

$46.7 \%(n=21)$ of the participants stated that there were shift systems in their workplaces. Of those stating that there was a shift system, $42.9 \%(n=9)$ mentioned that there were 2 shifts, while $57.1 \%(n=12) 3$ shifts.

The number of staffs ranged from 6 to 30, the mean was $11.71 \pm 4.57$ staff (Table 4).

It was found that $100 \%(n=45)$ of the participants did not informed about health risks in the workplace.

In terms of whether asking any question about possible health problems related to the work; $2.2 \%(\mathrm{n}=1)$ stated that they asked questions while $97.8 \%(\mathrm{n}=44)$ did not. Of those who did not ask any questions; the reason why they did not ask any question was listed as follow: $4.4 \%(n=2)$ due to ignorance, $86.7 \%(n=39)$ not-thought, $\% 4.4 \%(n=2)$ found unnecessary, $2.2 \%(n=1)$ since they were informed that there was no health risk, and $2.2 \%(n=1)$ supervisor didn't take care of themselves (Table 5).

In terms of taking a precaution for occupational safety; $86.7 \%$ $(\mathrm{n}=39)$ wear masks, $57.8 \%(\mathrm{n}=26)$ using goggles, and $37.8 \%$ $(n=17)$ using ventilation method (Table 4).

It was observed that $6.7 \%(n=3)$ of the patients had a term insurance, $93.3 \%(n=42)$ had no insurance. Of those who had a term insurance, one of them had a 1-month term insurance, one of them had a 2-month term insurance, and one of them had a 3-month term insurance (Table 4). 


\begin{tabular}{|c|c|c|c|}
\hline \multirow{4}{*}{\multicolumn{2}{|c|}{ The first reason to visit the doctor }} & A certain complaint & $5(11.1)$ \\
\hline & & Sickness of friend/relative & $28(62.2)$ \\
\hline & & The onset of the disease when in the army & $4(8.9)$ \\
\hline & & For seeing it as news in the media & $8(17.8)$ \\
\hline \multirow{5}{*}{\multicolumn{2}{|c|}{ Complaints }} & Fatigue, weight loss & $1(20.0)$ \\
\hline & & Cough, fatigue, weight loss & $4(80.0)$ \\
\hline & & After starting to work & $32(71.1)$ \\
\hline & & After quitting the work & $8(17.8)$ \\
\hline & & When in the army & $5(11.1)$ \\
\hline \multirow[t]{6}{*}{ Time to diagnosis } & \multirow[t]{2}{*}{ After starting to work $(n=32)$} & Min-Max (Median) & $5-18(8)$ \\
\hline & & $M e a n \pm S d$ & $9.00 \pm 3.39$ \\
\hline & \multirow[t]{2}{*}{ After quitting the work $(n=8)$} & Min-Max (Median) & $1-9(5.5)$ \\
\hline & & Mean $\pm S d$ & $5.00 \pm 2.51$ \\
\hline & \multirow[t]{2}{*}{ When in the army $(n=1)$} & Min-Max (Median) & 6 \\
\hline & & Mean $\pm S d$ & 6 \\
\hline \multirow{2}{*}{\multicolumn{2}{|c|}{ Procedures for diagnosis }} & Chest X-ray, blood test & $39(86.7)$ \\
\hline & & Chest X-ray, blood and sputum test & $6(13.3)$ \\
\hline \multirow{2}{*}{\multicolumn{2}{|c|}{$\begin{array}{l}\text { Tuberculosis diagnosis and treatment before silicosis } \\
\text { diagnosis }\end{array}$}} & Administered & $4(8.9)$ \\
\hline & & Not administered & $41(91.1)$ \\
\hline \multirow{2}{*}{\multicolumn{2}{|c|}{ Duration of treatment for silicosis }} & 6 Months & $3(75.0)$ \\
\hline & & 8 Months & $1(25.0)$ \\
\hline \multirow{3}{*}{\multicolumn{2}{|c|}{$\begin{array}{l}\text { After learning that he/she is a silicosis patient, } \\
\text { documenting that this is an occupational disease }\end{array}$}} & Yes & $1(2.2)$ \\
\hline & & No & $44(97.8)$ \\
\hline & & By applying to an occupational diseases hospital & $1(100.0)$ \\
\hline \multirow{4}{*}{\multicolumn{2}{|c|}{$\begin{array}{l}\text { Is there anyone else around you in the same situation } \\
\text { as you? }\end{array}$}} & No & $12(26.7)$ \\
\hline & & Friend & $26(57.8)$ \\
\hline & & Relative & $3(6.7)$ \\
\hline & & Friend and Relative & $4(8.9)$ \\
\hline \multirow{2}{*}{\multicolumn{2}{|c|}{ Getting legal rights }} & Yes & $0(0.0)$ \\
\hline & & No & $45(100.0)$ \\
\hline \multirow{5}{*}{\multicolumn{2}{|c|}{ Any institution interested in you? }} & Yes & $3(6.7)$ \\
\hline & & No & $42(93.3)$ \\
\hline & & District governor & 1 \\
\hline & & $\begin{array}{l}\text { Occupational diseases hospital calls for regular } \\
\text { check-up }\end{array}$ & 1 \\
\hline & & SSI & \\
\hline \multirow{3}{*}{\multicolumn{2}{|c|}{ Plans for the treatment of the disease in the next period }} & Regular check-up & $37(82.2)$ \\
\hline & & Following medical advice & $3(6.7)$ \\
\hline & & No plan & $5(11.1)$ \\
\hline
\end{tabular}

Table 5: Disease-Related Distributions 
Discussion and conclusion

This study, which was conducted to examine the exposure to silicate dust in people diagnosed with silicosis, aimed to evaluate the current status of individuals diagnosed with silicosis.

As a result of the evaluation of the questionnaires, it was observed that $91.1 \%$ of the laborers had to migrate for economic reasons, while $6.7 \%$ due to forced migration, and $2.2 \%$ for educational purposes. $100 \%$ of the individuals participating in the questionnaire $(n=45)$ verbally stated that they witnessed that their neighbors and relatives, who went to İstanbul to work due to economic difficulties in rural life, earned their living easily and supported those who remained behind financially, and this encouraged them to go to Istanbul and work as soon as possible.

In terms of the level of education, it was found that $6.7 \%(n=3)$ of the participants were literate, $29 \%(n=29)$ primary school, $4.4 \%(n=2)$ secondary school, $8 \%(n=17.8)$ high school and $6.7 \%(n=3)$ were university graduates.

All of the respondents $(100 \%)(n=45)$ stated that no preemployment health examination was made, so people started to be employed without observing their fitness for work. This made it impossible to find out whether individuals have an existing health problem. The health risks of the current environment of work was not questioned due to the need to meet the economic needs of the individuals who participated in our study as soon as possible.

The insufficient protective measures of the laborers, failure to apply on-site protective methods, and the thought of eliminating the process by providing only personal protective equipment have led to inevitable consequences. It is stated in the risk assessment regulations that on-site protection measures have priority over personal protective measures. While the use of masks (86.7\%) and goggles (57.8\%) as personal protective equipment were among the priority choices, ventilation in the workplace is at the level of $37.8 \%$. Although the rate of using masks and goggles seems to be high, the level of getting the disease remained high because the problem could not be solved on-site.

In light of all the results obtained, the subject should be given due importance since the health problems of an individual exposed to silicate dust and suffering from silicosis continue for many years. The applicable laws on silicate dust guide employers on what to do in this regard. However, it has been observed that there are serious deficiencies in practice and awareness. We believe that carrying out more studies, broadcasting public service announcements with written and visual media, and organizing necessary training by experts would contribute to increasing awareness in this regard.

In this study, the post disease processes of the cases were evaluated. This study, which expresses the most up-to-date epidemiological research results of today, is an original study in terms of expressing the process from diagnosis to the present day.

\section{Ethics approval}

The ethical approval was obtained from Scientific Research Ethics Committee of Social Sciences, Istanbul Medipol University (dated May 21, 2019, numbered 10840098604.01.01-E.16109).

\section{Authors' contribution}

All authors of this study have a complete contribution for data collection, data analyses and manuscript writing.

\section{Disclosure}

The authors declare that there are no conflicts of interest.

\section{References}

1. Sakar A, Kaya E, Celik P, Gencer N, Temel O, Yaman N, Sepit L, Yildirim CA, Dagyildizi L, Coskun E, Dinc G, Yorgancioglu A, Cimrin AH. (2005). Evaluation of silicosis in ceramic workers. Tuberkuloz ve Toraks Dergisi, 53(2):148-155.

2. Steenland K, \& Ward, E (2014). Silica: A lung carcinogen. CA: A Cancer Journal for Clinicians, 64(1):63-69. Doi:10.3322/caac.21214

3. Anlar HG (2017). Evaluation of Possible Genotoxic Damage in Ceramic Workers Due to Occupational Exposure, Hacettepe University Institute of Health Sciences, Ph.D. Thesis in Pharmaceutical Toxicology, Ankara.

4. Anlar HG, Bacanli M, Iritas S, Bal C, Kurt T, Tutkun E, Yilmaz OH, Basaran N (2017). Effects of Occupational Silica Exposure on OXIDATIVE Stress and Immune System Parameters in Ceramic Workers in TURKEY. Journal of Toxicology and Environmental Health, Part A, 80(13-15):688-696.

5. Akgün M, Araz O, Akkurt I, Eroglu A, Alper F, Saglam L, Mirici A, Gorguner M, Nemery B (2009). Kot Kumlama Iscilerinde Silikoz Epidemisi. TTB Mesleki Saglik ve Guvenlik Dergisi, 9(32):21-24.

6. Sun Y, Yang F, Yan J, Li Q, Wei Z, Feng H, Wang R, Zhang L, Zhang X (2010). New anti-fibrotic mechanisms of n-acetyl-seryl-aspartyl-lysyl-proline in silicon dioxideinduced silicosis. Life Sciences, 87(7-8):232-239.

7. Castranova V, Vallyathan V, Wallace WE (1995). Silica and silica-induced lung diseases. Eds., Boca Raton, FL: CRC Press, 1-432.

8. World Health Organization (WHO) (1948). Principles. https://www.who.int/about/mission/en/ (Last Accessed Date: $1 / 05 / 2020)$.

9. Charter O (1986). Ottawa Charter for health promotion. In First international conference on health promotion, pp. $17-21$.

10. Gunaydın D (2015). Decent Work: An Assessment for Turkey. The Journal of Academic Social Science Studies (JASSS), 37:123-148. 
11. Akkurt I. Mesleki Solunum Hastalıkları (2014). Ankara: Gunes Tip Kitabevleri.

12. Akkurt I (2014). Dünyada ve Ulkemizde Meslek Hastalıkları Tanı Sistemleri: Yeni Bir

Model Onerisi. TTB Mesleki Sagllk ve Guvenlik Dergisi, 14(51):30-38.

Copyright: C2021 Ozan Emre EYUPOGLU. This is an open-access article distributed under the terms of the Creative Commons Attribution License, which permits unrestricted use, distribution, and reproduction in anymedium, provided the original author and source are credited. 